\title{
АНАЛИЗ РЕЗУЛЬТАТИВНОСТИ НАЛОГОВЫХ ПРОВЕРОК
}

\author{
(c) 2018 Чотчаева Мадина Зулкарнаевна \\ кандидат экономических наук, доцент кафедры «Экономическая теория» \\ Северо-Кавказская государственная академия \\ 369000, г. Черкесск, ул. Ставропольская, д. 36 \\ E-mail:madinach@mail.ru \\ (c) 2018 Чеккуева Арина Азоховна \\ магистрант \\ Северо-Кавказская государственная академия \\ 369000, г. Черкесск, ул. Ставропольская, д. 36
}

В статье проведена оценка результативности налоговых проверок, выявлены тенденции основных показателей контрольной работы налоговых органов.

Ключевые слова: налоги, налоговый контроль, налоговые проверки, выездные налоговые проверки, камеральные налоговые проверки, налоговые органы, Карачаево-Черкесская республика.

В зависимости от того, насколько эффективно налажена система налогового контроля, зависит взимаемость налогов и пополнение государственного бюджета всех уровней. Ключевыми методами налогового контроля являются налоговые проверки. Они позволяют выявить факты неуплаты или неполной уплаты налогов и сборов. Налоговая проверка является значимым инструментом налогового контроля, дающим возможность как можно более полнее проверить исполнение налогоплательщиком возложенных на него обязанностей [3].

Для более полного и точного представления о проведении налоговых проверок ФНС России рассмотрим статистические данные о проведении налоговых проверок по РФ (табл. 1).

Анализ результативности налоговых проверок в Российской Федерации за 2015-2017 гг. в таблице показывает, что на фоне увеличения количества проведенных камеральных проверок на 23927061ед., снижается результативность камеральной налоговой проверки на с 6,1\% в 2015 г. до 5,4\% в 2017 г.. По выездным проверкам произошло снижение их общего количества на 34,03\%, но, несмотря на снижение количества выездных контрольных мероприятий уровень результативности остается высоким - более $98,67 \%$.

Таблица 1. Анализ проведения налоговых проверок по вопросам соблюдения законодательства о налогах и сборах в Российской Федерации за 2015-2017 гг.

\begin{tabular}{|c|c|c|c|c|c|c|}
\hline \multirow[b]{2}{*}{ Показатели } & \multirow[b]{2}{*}{2015 г. } & \multirow[b]{2}{*}{2016 г. } & \multirow[b]{2}{*}{2017 г. } & \multicolumn{3}{|c|}{ Темпы роста,\% } \\
\hline & & & & $\begin{array}{c}2016 \text { г. } \\
\text { к } 2015 \text { г. }\end{array}$ & $\begin{array}{c}2017 \text { г. } \\
\text { к } 2016 \text { г. }\end{array}$ & $\begin{array}{c}2017 \text { г. } \\
\text { к } 2015 \text { г. }\end{array}$ \\
\hline Камеральная налоговая проверка & 31932225 & 39977883 & 55859286 & 125,20 & 139,73 & 174,93 \\
\hline $\begin{array}{l}\text { Дополнительно начислено плате- } \\
\text { жей (включая налоговые санкции и } \\
\text { пени), тыс. рублей }\end{array}$ & 74233338 & 98922613 & 61174094 & 133,26 & 61,84 & 82,41 \\
\hline из них выявившие нарушения & 1948540 & 2254521 & 3013908 & 115,70 & 133,68 & 154,68 \\
\hline $\begin{array}{l}\text { Результативность камеральной } \\
\text { налоговой проверки,\% }\end{array}$ & 6,10 & 5,64 & 5,40 & 92,46 & 95,74 & 88,52 \\
\hline Выездная налоговая проверка & 29393 & 24879 & 19390 & 84,64 & 77,94 & 65,97 \\
\hline $\begin{array}{l}\text { Дополнительно начислено плате- } \\
\text { жей (включая налоговые санкции и } \\
\text { пени), тыс. рублей }\end{array}$ & 265239993 & 348660470 & 308356841 & 131,45 & 88,44 & 116,26 \\
\hline из них выявившие нарушения & 29118 & 24670 & 19133 & 84,72 & 77,56 & 65,71 \\
\hline $\begin{array}{l}\text { Результативность выездной налого- } \\
\text { вой проверки,\% }\end{array}$ & 99,06 & 99,16 & 98,67 & 100,10 & 99,51 & 99,61 \\
\hline
\end{tabular}


Преимущество же камерального контроля в том, что он позволяет с наименьшими затратами времени и усилий налогового органа проверить большое число налогоплательщиков на основе представленных ими налоговых деклараций и подтверждающих их документов.

ФНС в 2017 году значительно снизил количество проведенных выездных проверок, если в 2015 году ФНС России было проведено 29393 проверок, из них выявивших нарушения 29118 проверок, то в 2017 году было проведено 19390, что на 10003 меньше, чем в 2015 году.

На основе выше изложенного следует заключить, что за последние годы наблюдалось увеличение результативности налоговых проверок, при этом согласно целям ФНС России количество выездных проверок сокращалось. Кроме того, установление данных задач по повышению качества контрольно-аналитической работы оказало влияние на увеличение дополнительных доначислений налогов, пени и санкций [2].

Для более полного и точного представления о задолженности по налогам, сборам и иным налоговым платежам проведем анализ деятельности налоговых органов по вопросам соблюдения налогового законодательства в УФНС России по КЧР за 2015-2017 годы (табл. 2).

Анализ проведения налоговых проверок по вопросам соблюдения законодательства показал, что за исследуемый период количество камеральных налоговых проверок имеет тенденцию к росту на $46,3 \%$. Также стоит отметить, что результативность камеральных налоговых проверок за три года увеличилась на 7,2\%. Количество выездных налоговых проверок за рассматриваемый период снизилось на $49,7 \%$, а результативность увеличилась на $1,1 \%$.

Количество камеральных налоговых проверок превышает количество проведенных выездных налоговых проверок. Это не удивительно, так как проведение камеральной налоговой проверки является обязанностью налоговых органов. В связи с этим охват налогоплательщиков камеральными налоговыми проверками практически составляет сто процентов. Зачастую камеральная налоговая проверка служит основанием для проведения выездной налоговой проверки.

В настоящее время задолженность по налогам и сборам является одним из важнейших негативных экономических факторов. Задолженность по налогам и сборам - серьезная проблема, ограничивающая объем финансовых ресурсов в целом всей страны и решения ряда социальных государственных программ. Налоговая задолженность образуется под воздействием различных причин. Первоначальными причинами роста задолженности по налогам и сборам на наш взгляд является ухудшение финансового состояния хозяйствующих субъектов.

Ухудшение финансового благополучия можно связать с рядом негативных экономических тенденций, происходящих как в стране в целом, так и по субъектам Российской Федерации. К таковым причинам относятся:

- происходящие кризисные явления в стра-

Таблица 2. Анализ проведения налоговых проверок по вопросам соблюдения законодательства о налогах и сборах УФНС России по КЧР, ед.

\begin{tabular}{|c|c|c|c|c|c|c|}
\hline \multirow[b]{2}{*}{ Показатели } & \multirow[b]{2}{*}{2015 г. } & \multirow[b]{2}{*}{2016 г. } & \multirow[b]{2}{*}{2017 г. } & \multicolumn{3}{|c|}{ Темпы роста,\% } \\
\hline & & & & $\begin{array}{l}2016 \text { г. } \\
\text { к } 2015 \text { г. }\end{array}$ & $\begin{array}{c}2017 \text { г. } \\
\text { к } 2016 \text { г. }\end{array}$ & $\begin{array}{l}2017 \text { г. } \\
\text { к } 2015 \text { г. }\end{array}$ \\
\hline Камеральная налоговая проверка & 58579 & 68594 & 85718 & 111,7 & 124,3 & 146,3 \\
\hline $\begin{array}{l}\text { Дополнительно начислено плате- } \\
\text { жей (включая налоговые санкции и } \\
\text { пени), тыс. рублей }\end{array}$ & 38817 & 62410 & 57435 & 160,8 & 92,0 & 148,0 \\
\hline из них выявившие нарушения & 4835 & 4833 & 7595 & 99,9 & 157,1 & 157,1 \\
\hline $\begin{array}{l}\text { Результативность камеральной } \\
\text { налоговой проверки,\% }\end{array}$ & 8,25 & 8,20 & 8,86 & 84,3 & 127,1 & 107,2 \\
\hline Выездная налоговая проверка & 189 & 124 & 95 & 65,6 & 76,6 & 50,3 \\
\hline $\begin{array}{l}\text { Дополнительно начислено плате- } \\
\text { жей (включая налоговые санкции и } \\
\text { пени), тыс. рублей }\end{array}$ & 856901 & 173983 & 290305 & 20,3 & 166,9 & 33,9 \\
\hline из них выявившие нарушения & 187 & 123 & 95 & 65,8 & 77,3 & 50,8 \\
\hline $\begin{array}{l}\text { Результативность выездной налого- } \\
\text { вой проверки,\% }\end{array}$ & 98,94 & 99,19 & 100,00 & 100,3 & 100,8 & 101,1 \\
\hline
\end{tabular}


Таблица 3. Динамика налоговой задолженности УФНС России по КЧР за 2015-2017 годы, тыс. руб.

\begin{tabular}{|l|c|c|c|c|c|}
\hline \multicolumn{1}{|c|}{ Показатели } & & & \multicolumn{2}{|c|}{ Темпы роста,\% } \\
\cline { 3 - 7 } & 2015 г. & 2016 г. & 2017 г. & $\begin{array}{c}2016 \text { г. } \\
\text { к 2015 г. }\end{array}$ & $\begin{array}{c}2017 \text { г. } \\
\text { к 2016 г. }\end{array}$ \\
\hline Задолженность перед бюджетом по налогам и сборам & 2386858 & 1805663 & 2929201 & 75,65 & 162,22 \\
\hline $\begin{array}{l}\text { Задолженность по налогам и сборам не возможная к } \\
\text { взысканию }\end{array}$ & 30694 & 51572 & 35475 & 168,02 & 68,79 \\
\hline Урегулированная задолженность & 788355 & 347733 & 301325 & 44,11 & 86,65 \\
\hline
\end{tabular}

не;

- высокая налоговая нагрузка;

- низкая эффективность судебной системы РФ и т.д.

Независимо от того, какая задолженность рассматривается и анализируется в совокупности, она подразделяется на два вида:

- урегулированная налоговая задолженность;

- неурегулированная налоговая задолженность.

К урегулированной налоговой задолженности следует отнести налоговую задолженность, по отношению которой применены методы урегулирования со стороны налоговых органов РФ. Неурегулированная задолженность состоит из задолженности невозможной к взысканию, а также из недоимки, то есть величины налога неуплаченного в установленный срок, в отношении которой сроки применения мер взыскания и урегулирования путем изменения срока уплаты действительны.

В связи с этим необходимо провести анализ динамики и ключевых факторов формирования налоговой задолженности. Анализ проводился на основе данных УФНС России по КЧР (табл. 3).

По данным таблицы 3 видно, что задолженность перед бюджетом по налогам и сборам за 2015-2016 гг. имеет тенденцию к снижению на 581195 тыс. руб. или на $24,35 \%$, а за 20162017 гг. - к повышение на 1123538 тыс. руб. или на $62,2 \%$. В результате за рассматриваемый период с 2015-2017 гг. задолженность перед бюджетом по налогам и сборам увеличилась на 542343 тыс. руб. или на 22,72\%.

Задолженность по налогам и сборам не возможная к взысканию за 2015-2016 гг. увеличилась на 20878 тыс. руб. или на 68,02\%, за 2016-
2017 гг. в отличие от предыдущего периода наблюдается снижение уровня задолженности на 16097 тыс. руб. или на 31,21\%. За весь рассматриваемый период, т.е. за три года задолженность не возможная к взысканию налоговыми органами увеличилась на 15,58\%.

Ситуация с урегулированной задолженностью следующая: за 2015-2016 гг. снизилась на 440622 тыс. руб. или на 55,99\%, за 2016-2017 гг. уровень урегулированной задолженности продолжил снижение на 46408 тыс. руб. (13,35\%).

В последние годы Федеральная налоговая служба сделала акцент на необходимость активного побуждения налогоплательщиков, в деятельности которых выявлены налоговые риски, к добровольному уточнению налоговых обязательств без назначения выездных налоговых проверок. И это приносит ощутимые результаты, так удается обеспечить стабильный рост поступлений и по результатам контрольно-аналитической работы [1].

Однако сложившийся механизм проведения выездных налоговых проверок не обеспечивает требуемого на сегодняшний день уровня эффективности деятельности налоговых органов, потому что данный процесс сопровождается многочисленными проблемами. В связи с этим, проблема эффективности налогового контроля, в том числе проблема эффективности налоговых проверок является актуальной [3].

Очевидно, что для обеспечения доходной части государственного бюджета необходимо дальнейшее реформирование контрольной работы ФНС РФ, в первую очередь за счет взаимодействия налоговых органов и налогоплательщиков, направленное на предупреждение налоговых нарушений.

\section{Библиографический список}

1. Итоги деятельности ФНС России за 2017 год- https://www.nalog.ru/rn77/related_activities/statistics_and_ analytics/effectiveness/\#t31. 
2. Солнышкова Ю.Н. Пути повышения эффективности проведения налоговых проверок/ Солнышкова Ю.Н.// Наука и общество. 2017. № 3 (29). С. 50-58.

3. Шестакова Н.Н., Елисеев М.Е. Проблемы эффективности выездных налоговых проверок/ Шестакова Н.Н., Елисеев М.Е.// Евразийский союз ученых. 2018. № 4-6 (49). С. 49-52.

Поступила в редакцию 29.12.2018 